\title{
Cash transfers and female labor force participation: the case of $\mathrm{AUH}$ in Argentina

\author{
Santiago Garganta* ${ }^{*}$, Leonardo Gasparini and Mariana Marchionni
}

\author{
* Correspondence: \\ sangarganta@hotmail.com \\ Centro de Estudios Distributivos, \\ Laborales y Sociales (CEDLAS) - \\ Facultad de Ciencias Económicas, \\ Universidad Nacional de La Plata \\ and CONICET, La Plata, Argentina
}

\begin{abstract}
In this paper, we estimate the impact on female labor force participation of a massive conditional cash transfer program-Universal Child Allowance, AUH_launched in Argentina in 2009. We identify the intention-to-treat effect by comparing eligible and non-eligible women over time through a diff-in-diff methodology. The results suggest a negative and economically significant effect of the program on female labor force participation. The disincentive to participate is present for married women, while the effect is not statistically significant for unmarried women with children. We also find evidence on the heterogeneity of the effect depending on woman's education, husband's employment status, number and age of children, and whether the woman is the main responsible of domestic chores. The relatively large value of the benefit and the fact that transfers are mostly directed to mothers may explain the sizeable effect of the program on female labor supply. The welfare implications of the results are not clear and deserve further inspection.
\end{abstract}

JEL Classification: H53, 138, J16, J22

Keywords: Labor participation, Cash transfers, Social protection, AUH, Argentina

\section{Introduction}

All countries in Latin America launched initiatives to extend social protection, in particular through the implementation of conditional cash transfer (CCT) programs targeted to poor households with children. The literature that analyzes these social protection schemes has strongly grown over the last years. ${ }^{1}$ The evidence suggests that these programs have played a very important role in the short-term reduction of poverty and income inequality in the region and in the promotion of human capital accumulation in poor families (Fiszbein and Schady 2009; Ibarrarán et al. 2017). However, there is concern about some potential unintended effects of these programs; in particular, they may imply a labor supply disincentive and a bias towards unregistered labor arrangements (Levy 2008; Levy and Schady 2013; Garganta and Gasparini 2015). Moreover, disincentives to labor market participation may be gender biased. The monetary subsidy raises household income and therefore may reduce the need for an extra paid job, typically provided by the female spouse. Female labor supply may be discouraged through an additional channel, given that women are typically the recipients of the transfers. If the subsidy is perceived as income earned by mothers, it may release them from the pressure to seek employment or to work longer hours. ${ }^{2}$

(c) The Author(s). 2017 Open Access This article is distributed under the terms of the Creative Commons Attribution 4.0 International License (http://creativecommons.org/licenses/by/4.0/), which permits unrestricted use, distribution, and reproduction in any medium, provided you give appropriate credit to the original author(s) and the source, provide a link to the Creative Commons license, and indicate if changes were made. 
The existence and quantitative relevance of these unintended effects are at the core of the current social protection debate in Latin America. The economic literature on the impact of massive income programs on the labor markets is still incipient but growing. ${ }^{3}$ This study contributes to this literature by assessing the potential impact on female labor force participation of a large cash transfer program implemented in Argentina, targeted to poor unregistered households with children. Specifically, the Universal Child Allowance for Social Protection (AUH for its acronym in Spanish) provides a monthly benefit per child to households whose members are unemployed or working in the informal sector (i.e., unregistered). The AUH is a massive conditional cash transfer program launched in 2009, which covers around $30 \%$ of all children under 18 years and more than two million families in Argentina (15\% of total households in the country). The real value of the AUH benefit per child, which has remained relatively constant over time, represents $14 \%$ of the legislated minimum wage and hence a significant rise of the mean household income for unemployed and informal households with children (i.e., the potential beneficiaries of the program). For a typical poor participant household with three children, the benefit implies an increase of almost $35 \%$ in their total household income. These values place the AUH benefit among the largest in Latin America (Stampini and Tornarolli 2013).

Cash transfers to poor informal households with children may reduce the parents' participation in the labor market compared to the counterfactual situation in the absence of the program. ${ }^{4}$ We expect this effect to be higher for mothers due to at least two arguments. The first one is that the income elasticity of labor supply tends to be larger for females than for males, in particular for married women with children (Michalopoulos et al. 1992; Kimmel 1998; Eissa and Hoynes 1999; Eissa and Hoynes 2004; Naz 2004; Tamm 2009). ${ }^{5}$ This difference is mainly driven by the fact that many women decide their employment status sequentially in response to the decision of their husbands or partners (Michalopoulos et al. 1992). Female labor decisions are more flexible when they are not the only income earners of the household or the principal worker of the family (Kimmel 1998). ${ }^{6}$ In Latin America, the role of women as secondary workers is reinforced by solid traditional family structures with a strong attachment to traditional gender roles and low levels of women's skills and educational attainment.

The second argument relies on the fact that women are typically the recipients of the subsidy. Administrative data from the AUH program (ANSES 2014) reveals that in $96 \%$ of the beneficiary households, the mother is identified as the principal holder/recipient of the benefit. If the benefit is perceived as an income earned by mothers for taking care of the children and checking the conditionalities of the program, it may discourage the search for an additional job in the market. In summary, the program may reduce the economic need for mothers to be actively engaged in the labor market and the family/social pressure to do so.

Although there are reasons to believe that the AUH may reduce the incentives to participate in the labor market, in practice, these disincentives could be quantitatively irrelevant or be compensated by forces operating in other directions. The actual relevance of the potential disincentives of the program can only be determined with empirical evidence. Unfortunately, it is not simple to identify the causal effect of the program since it was not randomly assigned in the population. In addition, no questions aimed at identifying AUH beneficiaries were introduced in the national household 
survey of Argentina. Due to these constraints, our identification strategy consists in comparing eligible mothers (poor and informal with children) with similar but noneligible women over time. This strategy of difference-in-differences is effective in alleviating several endogeneity problems that arise when comparing heterogeneous observations.

The evidence we present in this paper suggests fewer transitions from inactivity to labor force participation for eligible mothers after the inception of the AUH, especially among married women. The effect is not negligible: on average, it represents a fall of $24.7 \%$ in the probability of participating in the labor market, compared to what would have happened in the absence of the program. We argue that the large size of the cash benefit may account for such a sizeable effect. The program also seems to affect female hours of work, although this result is not entirely robust to alternative definitions of the control group. In contrast, both labor participation and total hours worked by men are not significantly changed by the introduction of the AUH.

Interestingly, we also find an asymmetric labor adjustment to the program: while it seems to reduce the transitions of inactive women to labor force participation, it does not significantly affect the transitions from labor activity to inactivity. Given these differential effects on female labor transitions, we conclude by suggesting that the observed reduction in the labor participation rate among eligible women after the $\mathrm{AUH}$-in comparison with a more stable trend for non-eligible women-is mainly explained by a slower entry of eligible women into the labor force and not to a significant increase in the exit rate.

The welfare implications of these results are not clear and deserve further research. The discouragement of female labor force participation can not only be assessed as a setback in terms of women's empowerment, gender equality, and poverty relief but can also be seen as a positive outcome of the program, if the subsidy allows poor women to leave low-quality jobs to devote time to take care of their children or to seek for better employment opportunities. ${ }^{7}$

The rest of the paper is organized as follows. Section 2 reviews the literature on social policy and labor force participation. In Section 3, we explain the main characteristics of the Universal Child Allowance program and discuss its potential effects on labor force participation. Section 4 describes the data used in this study and lays out the methodology, while Section 5 presents the main findings. We conclude in Section 6 with some final remarks.

\section{Literature and background}

There is a large variety of cash transfer programs implemented around the world with potential consequences on the labor outcomes of the beneficiaries, particularly on women's participation. Leibbrandt et al. (2013) analyze the various mechanisms involved in the employment decisions of individuals facing the introduction of these policies, stressing their significant incidence on female labor variables. These benefits may entail a strong labor impact on women who are traditionally characterized by low participation rates and an active involvement in household chores and childcare.

One of the income policies with high incidence on female labor participation is the child support grants (CSG). This type of program, implemented by several countries, consists of a cash transfer targeted to households with children focused on easing the 
childcare process. The objective of CSGs is twofold: improve the quality of childcare and reduce its cost. The evidence indicates that the impact of these programs on labor supply depends strongly on which of these two purposes dominates and how mothers internalize this benefit. Kimmel (1998) shows that the change in childcare price generated by CSG programs tends to restrict the labor supply particularly of married women considering they are not the only income earner of the family. In the USA, women react to this type of income transfer substituting childcare services but without altering their employment rate (Ribar 1995). Other authors find instead an increase in female participation and labor intensity due to the introduction of CSGs both in developed and developing countries (Williams 2007; Lefebvre and Merrigan 2008; Eyal and Woolard 2011). Berger and Black (1992) reveal that women invest this transfer directly on her children, increasing schooling attendance, which enables mothers to devote a higher proportion of their time in the labor market. If this benefit is not exclusively assigned to the child, it can generate a reduction in labor costs for mothers (e.g., financing job-seeking) and therefore may raise their labor force participation (Lefebvre and Merrigan 2008).

Another important group of programs with significant impact on labor results are those universal cash transfers or other minimum income benefits based on certain eligibility criteria (means-test grants). These policies may induce either a positive effect on labor supply (lower labor fixed costs) or a negative change on participation, particularly when the amount of the benefit is close to the potential labor income (Franz et al. 2011). However, the literature shows a relative consensus for this group of programs. The evidence suggests an adverse effect on labor supply, particularly motivated by the lack of conditionalities and the magnitude of the benefits. Lemieux and Milligan (2004) identify a significant reduction both of the employment rate and the total hours worked by participants of a social assistance transfer in Quebec. Terracol (2009) and Bargain and Doorley (2011) evaluate the impact on the labor market of a means-tested program in France. They find an important fall in labor participation and larger unemployment duration, since the transfer reception does not require any condition on seeking job. Similarly, Cavalcanti and Correa (2010) find a negative labor effect of a cash transfer program in Rio de Janeiro which benefits individuals with income below a certain threshold regardless of their employment status. There is also evidence of a differential impact between genders of these programs. For instance, a minimum income policy in Albania discourages labor market participation, particularly of women living in urban areas (Dabalen et al. 2008).

The conditional cash transfers, mainly implemented in Latin America, can also generate diverse labor effects. The evidence on these CCT programs is still scarce and far from conclusive (Bosch and Manacorda 2012). Although several studies have found no significant labor consequences in the short term (Amarante et al. 2011, 2011; Alzúa et al. 2013; Galasso 2006; Skoufias and Di Maro 2008; Skoufias et al. 2008; Edmonds and Schady 2012; Banerjee et al. 2015), some papers provide evidence that CCTs may discourage labor supply in certain groups. Medeiros et al. (2008) reveal that the program Bolsa Familia in Brazil reduced the probability of labor participation among eligible women. Similarly, Ferro and Nicollela (2007), Teixeira (2010), and Scarlato et al. (2014) find that some CCT programs have implied a decline in hours worked by women, in particular those with greater restrictions to meet the requirements of these policies and 
with less assistance from other household members in domestic tasks. Accordingly, Gammage (2010) sets forth the importance to consider the potential incidence of these programs on women time distribution between unpaid domestic activities and labor market participation. Parker and Skoufias (2000) who show no major labor disincentive effects from the Mexican CCT program (Oportunidades) do find instead a significant increase of female hours aimed to fulfill the obligations set by the program.

In reference to the $\mathrm{AUH}$, the main CCT in Argentina, the evidence related to its labor impact is also incipient and mixed. Some previous studies show that the program generated relevant labor disincentives (Boffi 2013; Garganta and Gasparini 2015; Castillo et al. 2013) while others fail to find significant changes in adults' labor supply (Maurizio and Vazquez 2014; Kliksberg and Novacovsky 2015). For instance, Maurizio and Vazquez (2014) find a slightly significant but not robust increase in the unemployment rate of beneficiary women. These authors, however, use a different identification strategy and analyze the evidence over a shorter period of time (2009-2010) than our study. In contrast, Castillo et al. (2013) highlight the greater labor precariousness of the AUH participants compared to those workers under the traditional social security system (TSS). They also reveal the lower chance of access to a stable job of the AUH beneficiaries and the relatively worse paid employment they take on. These authors also report a smaller participation rate among recipients and a higher probability of underemployment than TSS workers. They state that this policy reinforces the determination of women as the principal child care provider of the household. Although this can be positive in some respects, it can also perpetuate the traditional domestic roles assigned to them and strengthen their isolation from the labor market.

This paper considers that the AUH may generate a reallocation of roles between genders with a potential reduction in female labor participation. The hypothesis is supported by several arguments detailed in Section 3, some of them are based on general empirical issues, and others are linked to the particular design of this policy.

\section{The AUH and its potential effects on labor market participation}

In November 2009-under stable economic conditions and with ample political support-the Argentinian government implemented a massive program of conditional cash transfers to poor households. ${ }^{8}$ Specifically, the decree 1602/09 created the Universal Child Allowance for Social Protection (AUH) which consists of a monetary subsidy per child for households whose members are either unemployed or working in the informal sector (unregistered workers). ${ }^{9}$ The decree also restricts participation to those unregistered workers earning less than the legal minimum wage. However, this limitation is inconsequential in practice since earnings of informal workers are difficult to monitor.

As any typical conditional cash transfer program (CCT), the AUH requires compliance with education and health conditions: vaccination and health checks for children under age 4 and for pregnant women and school attendance for children aged 5 through 18. To enforce these conditions, the program sets a particular payment mechanism: $80 \%$ of the subsidy is automatically received by beneficiary families on a monthly basis, and the remaining $20 \%$ is paid annually, once compliance with the conditionalities is proven. If the conditions are not met, not only the $20 \%$ is not perceived but also the beneficiary is suspended from future participation in the program. 
The program covers a large proportion of the Argentinian population, the majority belonging to low-income strata. Currently, the AUH covers almost four million children, which accounts for one third of all children in the country and $15 \%$ of total households. The annual budget of the program-around $0.8 \%$ of GDP-is one of the highest in Latin America. The monetary benefit is also high according to international standards (Fiszbein and Schady 2009; Stampini and Tornarolli 2013). At the time of its inception, the AUH transferred ARS 180 (around USD 50) per month for each child under 18 years old up to a maximum of five dependent children per family. ${ }^{10}$ The monthly amount per child has been adjusted several times to shield the purchasing power of the subsidy against inflation. By June 2015, the monthly transfer per child was ARS 837, representing around $12 \%$ of the mean household income for unemployed and informal households with children and $14 \%$ of the legislated minimum wage. ${ }^{11}$ For a typical poor beneficiary family with three children, the benefit implies an increase of $35 \%$ in total household income. The recipients of AUH are not allowed to receive benefits from other social programs.

Being such a large program, the AUH may have a potentially significant impact on economy-wide social and labor variables. The existing literature finds that the AUH had a significant impact on the reduction of poverty and income inequality (Gasparini and Cruces 2010; Agis et al. 2010), discouraged labor market formalization (Garganta and Gasparini 2015), and increased school attendance (Edo et al. 2015). Although there are also some few estimations of the effect of the AUH on adult's labor supply, no conclusive evidence was found in this regard (Boffi 2013; Castillo et al. 2013; Maurizio and Vazquez 2014; Kliksberg and Novacovsky 2015) and there are still no studies assessing the impact of this program on labor participation with a main focus on the potential gender bias that CCTs could actually incite.

There are several reasons to relate the AUH with a potential work disincentive, particularly for women. The income effect associated to the cash transfer may discourage labor participation of beneficiary family members, but especially of mothers for at least two reasons. First, income elasticity of labor supply tends to be larger for women than for men, particularly for women who act as secondary workers within their household (Michalopoulos et al. 1992; Kimmel 1998; Eissa and Hoynes 1999; Eissa and Hoynes 2004; Naz 2004; Tamm 2009). Many women decide their employment status sequentially in response to the decision of their husbands or partners (Michalopoulos et al. 1992). As a consequence, female labor decisions are more flexible when they are not the only income earners of the household (Kimmel 1998). In particular, Latin American women are likely to act as secondary workers because of the persistent strong attachment to traditional gender roles and the low levels of women's skills and educational attainment in the region.

The second reason relies on the fact that women are typically the recipients of the cash transfer. According to administrative data from the AUH (ANSES 2014), the mother is the principal holder/recipient of the benefit in $96 \%$ of the participant households. Therefore, beneficiary women may perceive the transfer as earned income in exchange for their efforts to ensure compliance with the conditionalities of the program, which encourages the traditional division of gender roles within the household and reduces the pressure on women to seek for a job outside the house. In summary, the AUH may reduce the economic need of mothers to be actively engaged in the labor market and the family/social pressure to do so. 


\section{Data and methodology}

Our analysis is based on microdata from Argentina's national household survey (Encuesta Permanente de Hogares, EPH) quarterly conducted by the national statistical office (INDEC). The EPH covers 31 large urban areas, which represent $62 \%$ of total country population. Since we aim to assess whether the AUH affected female labor supply, we exploit the rotation sampling of the EPH that allows us to observe changes in labor variables over time for each individual in the sample. Specifically, we observe each woman in the survey in two successive quarters, and then, we observe her again 1 year later in the same two consecutive quarters. In particular, we are interested in the transition from inactivity to activity, i.e., women who were inactive in the first round of observation (semester) and experienced a transition towards activity in the last one, either by working or by actively looking for a job. ${ }^{12}$

We focus on the period 2005-2013. Since the AUH was launched in November 2009, the pre-intervention or "before" period includes years 2005 through 2009 while the post-intervention or "after" period covers years 2010 through 2013. ${ }^{13}$ Our sample includes inactive women between 20 and 60 years old who are the spouse or the head of their households. Since the EPH does not include questions to identify AUH beneficiaries, we aim at determining whether the household is a potential beneficiary of the program by checking the eligibility criteria-intention to treat. Specifically, the treatment group is composed of inactive women with children under age 18 who live in poor and informal households. By informal household, we mean that neither the woman nor her spouse is registered in the national social security system. ${ }^{14}$ This is the case for unemployed and inactive individuals, unregistered workers, and, typically, self-employed workers. ${ }^{15}$ We define poor families as those belonging to the first four deciles of the household per capita income distribution. ${ }^{16}$ The control group includes the rest of the women in our sample, i.e., inactive women between 20 and 60 years old who do not meet all the conditions to be eligible. In the next section, we show that the results are robust when using alternative control groups.

Table 1 shows descriptive statistics of the treatment and control groups, both before and after the inception of the AUH. Beyond some similar features between the two groups, they exhibit, as expected, significant differences: eligible women are poorer, younger, and less educated and have more children and larger families than women in the control group.

Given that these discrepancies hold over time (before and after the AUH) and with no significant changes on their magnitude, we apply a difference-in-differences methodology in order to estimate the impact of the AUH on female labor participation. Specifically, we compare the differences in the outcome of interest-the probability to make a transition from inactivity to activity-between the treatment and the control group, before and after the introduction of the program (Card 1990; Card and Krueger 1994; Bertrand et al. 2004). The identification assumptions are that labor force participation trends for both treatment and control groups would have been similar in the absence of the AUH and that there were no other contemporaneous events to the implementation of the AUH that could have caused a differential impact on that outcome between the two groups. The latter does not appear to be a strong assumption considering that no new social programs nor labor market reforms took place during the period under analysis. In fact, the AUH was the consequence of a political debate 
Table 1 Descriptive statistics of estimation sample. Women aged 20-60-head of household or spouse

\begin{tabular}{|c|c|c|c|c|c|c|c|c|c|c|}
\hline \multirow[t]{3}{*}{ Variables } & \multicolumn{5}{|c|}{ Before AUH } & \multicolumn{5}{|c|}{ After AUH } \\
\hline & Treat & Control & Diff. & $t$ & $p$ value & Treat & Control & Diff. & $\mathrm{t}$ & $p$ value \\
\hline & (i) & (ii) & (ii)-(i) & & & (i) & (ii) & (ii)-(i) & & \\
\hline Age & 37.3 & 44.6 & 7.30 & 30.8 & 0.00 & 37.3 & 44.2 & 6.88 & 26.5 & 0.00 \\
\hline Years of education & 8.20 & 9.73 & 1.53 & 20.0 & 0.00 & 8.40 & 9.91 & 1.50 & 18.5 & 0.00 \\
\hline Married women (\%) & 0.86 & 0.88 & 0.02 & 2.75 & 0.01 & 0.84 & 0.87 & 0.03 & 4.20 & 0.00 \\
\hline $\begin{array}{l}\text { Women with } \\
\text { employed partner (\%) }\end{array}$ & 0.87 & 0.87 & 0.00 & -0.44 & 0.66 & 0.87 & 0.87 & 0.01 & 0.83 & 0.41 \\
\hline Household head (\%) & 0.19 & 0.15 & -0.04 & -4.92 & 0.00 & 0.25 & 0.19 & -0.06 & -5.99 & 0.00 \\
\hline Number of children & 2.71 & 1.07 & -1.65 & -54.07 & 0.00 & 2.55 & 1.04 & -1.52 & -48.60 & 0.00 \\
\hline Number of members & 5.48 & 4.17 & -1.31 & -32.40 & 0.00 & 5.34 & 4.08 & -1.26 & -28.81 & 0.00 \\
\hline $\begin{array}{l}\text { Number of women } \\
\text { (20-60 years old) }\end{array}$ & 1.22 & 1.37 & 0.16 & 11.68 & 0.00 & 1.22 & 1.35 & 0.13 & 9.12 & 0.00 \\
\hline $\begin{array}{l}\text { Number of men } \\
\text { (20-65 years old) }\end{array}$ & 1.11 & 1.25 & 0.14 & 9.18 & 0.00 & 1.10 & 1.24 & 0.14 & 8.02 & 0.00 \\
\hline $\begin{array}{l}\text { Women in charge of } \\
\text { domestic chores (\%) }\end{array}$ & 0.96 & 0.94 & -0.02 & -4.20 & 0.00 & 0.95 & 0.94 & -0.01 & -1.75 & 0.08 \\
\hline $\begin{array}{l}\text { Partner in charge of } \\
\text { domestic chores (\%) }\end{array}$ & 0.05 & 0.06 & 0.01 & 1.04 & 0.30 & 0.06 & 0.07 & 0.01 & 1.62 & 0.10 \\
\hline $\begin{array}{l}\text { Household per } \\
\text { capita income }\end{array}$ & 157.23 & 563.09 & 405.86 & 34.72 & 0.00 & 431.61 & 1405.84 & 974.22 & 33.29 & 0.00 \\
\hline Observations & 2842 & 9374 & & & & 2505 & 7530 & & & \\
\hline
\end{tabular}

Source: Authors' calculation based on EPH data. Note 1: the sample includes all inactive women between 20 and 60 years old who are the spouse or the head of their households. The treatment group is composed of inactive women with children under age 18 who live in poor (first four deciles of the household per capita income distribution) and informal households (neither the woman nor her spouse is registered in the national social security system) while the control group includes the rest of the inactive women in our sample who do not meet all the conditions to be eligible. Before AUH: 2005-2009. After AUH: 2010-2013. Note 2: Married women refers both to legally married women and women in consensual unions

on the need to revitalize the social policy in Argentina. While the first assumption cannot be proven, in the next section, we provide evidence to gain confidence in its validity.

Equation 1 represents the typical standard linear specification of the diff-in-diff model.

$$
\mathrm{FP}_{i t}=\alpha+\beta_{1} \text { Treat }_{i}+\beta_{2} \text { After }_{t}+\gamma \text { Treat }_{i} \text { After }_{t}+\theta X_{i}+u_{i t}
$$

The outcome variable $\mathrm{FP}_{i t}$ is a binary indicator taking the value 1 for inactive women $i$ who make the transition to activity in the labor market in year $t$ and the value 0 otherwise. More precisely, if a woman $i$ is inactive during her first two appearances in the survey but in the last two interviews- 1 year after the first one-she does work or is actively looking for a job, then the dummy variable $\mathrm{FP}_{i t}$ equals $1 .^{17}$ The model includes the indicator variable Treat that takes the value 1 for the treatment group, the dummy variable After that switches on for observations in post-intervention years 2010 through 2013, an interaction term between them, and a set of individual and household-level controls represented by vector $X .^{18}$ Individual controls include age, age squared, educational level, marital status, whether the male spouse is employed, and binary indicators of the head of household and of whether the woman is in charge of household chores or whether other family members help with those tasks. Household controls include per capita family income, family size, and number of family members by age and gender-number of women aged 20 to 60 , men aged 20 to 65, and children under age 18. Also, vector $X$ includes region and time fixed effects. 
Instead of a linear model, we carry out the analysis using the nonlinear specification in Eq. 2, where the conditional expectation of the dependent binary variable is a nonlinear function that follows a Probit specification.

$$
\operatorname{Pr}\left(\mathrm{FP}_{i t}\right)=\Phi\left(\alpha+\beta_{1} \text { Treat }_{i}+\beta_{2} \text { After }_{t}+\gamma \text { Treat }_{i} \text { After }_{t}+\theta X_{i}\right)
$$

where $\operatorname{Pr}($.$) denotes probability. The impact of the program is estimated as$

$$
D D=\Phi\left(\alpha+\beta_{1}+\beta_{2}+\gamma+\theta X_{i}\right)-\Phi\left(\alpha+\beta_{1}+\beta_{2}+\theta X_{i}\right)
$$

It is worth to mention that in the nonlinear model, the expected value of the potential outcome is not zero as in the linear specification. The treatment effect in this diffin-diff nonlinear model is the difference between two cross differences: the difference of the conditional expectation of the observed outcome (factual) minus the cross difference of the conditional expectation of the potential or counterfactual outcome. As it is shown in Eq. 3, the treatment effect will then be the incremental probability impact caused by the coefficient of the interaction term (Ai and Norton 2003; Puhani 2012). Being $\Phi($.$) a strictly monotonic nonlinear function, the sign of \gamma$ will always coincide with the sign of the treatment effect. These results apply to all nonlinear models with this parametric structure.

\section{Results}

In this section, we present and discuss the results of estimating the diff-in-diff probit model in Eq. 2 to evaluate the effect of AUH's eligibility on the probability of entering the labor market for inactive women. We also estimate the effects on other labor transitions potentially affected by the AUH: from activity to inactivity and from employment to being not employed. Besides these extensive-margin outcomes, at the end of this section, we evaluate the effects on the intensive margin of labor supply by estimating the impact on hours of work.

Female transitions from inactivity to activity seem to have been affected by the AUH. As Table 2 shows, the mean proportion of eligible inactive women that enter the labor force decreased almost 2.2 percentage points after the introduction of the program, which contrasts with the almost null change in the control group. ${ }^{19}$

To reinforce our confidence on the preliminary evidence from Table 2, we test for common trends between groups before the introduction of the program. For this purpose, we run a model of the outcome variable on a constant, the treatment dummy, year dummies, and interactions between the treatment and year dummy variables

Table 2 Proportion of inactive women entering the labor force. Treatment and control group, before and after $\mathrm{AUH}$

\begin{tabular}{llll}
\hline & Treatment (i) & Control (ii) & (i)-(ii) \\
\hline Before AUH (a) & 10.3 & 7.1 & 3.3 \\
After AUH (b) & 8.1 & 6.9 & 1.3 \\
Difference after-before: (a)-(b) & -2.2 & -0.2 & -2.0 \\
\hline
\end{tabular}

Source: Authors' calculation based on EPH data. Note: the sample is composed of inactive women between 20 and 60 years old who are the spouse or the head of their households. The treatment group includes inactive women with children under age 18 who live in poor (first four deciles of the household per capita income distribution) and informal households (neither the woman nor her spouse is registered in the national social security system) while the control group includes the rest of the inactive women in our sample who do not meet all the conditions to be eligible. Before AUH: 2005-2009. After AUH: 2010-2013 
including only pre-intervention periods. We then apply an $F$ test in which the null hypothesis states that all the coefficients for the interaction terms are jointly equal to zero. We find no evidence to reject the null hypothesis for all women in our sample. ${ }^{20}$ Therefore, the result suggests the existence of a common underlying trend for the treatment and control groups before the implementation of the AUH, which then appears to have been broken since the introduction of the program.

This initial evidence arises from an unconditional analysis, and hence, it must be confirmed through a more robust estimation of the treatment effect. In what follows, we show that the result holds in a multivariate regression framework. Table 3 reports the estimated change in the probability of the transition from inactivity to activity associated to the AUH, applying the diff-in-diff probit model in Eq. 2. The results suggest a negative and significant effect of the AUH on the probability that inactive women enter the labor force. This disincentive to participate is present among married women-both legally married or in consensual unions-while the effect is not significant for unmarried women with children. The estimated impact among married mothers accounts for a 2.62 percentage point drop in the probability of making the transition to labor force participation, which represents a reduction of $24.7 \%$ in the expected outcome of eligible women in the absence of the AUH. On the other hand, the effect of the program on eligible men is smaller and not statistically significant. These results are consistent with the arguments discussed in Section 3: unlike men and single women, married women usually act as secondary workers within their households; hence, their labor market participation decisions are likely to be more sensitive to the income transfers from the program. ${ }^{21}$ Given the heterogeneity found in Table 3, the following results focus on the group of married women only.

The key identifying assumption of this causal impact is that eligible women would have behaved similar to the control group in the absence of the AUH. The evidence of common trends before the AUH suggests that this was the case in the pre-intervention period, but the assumption itself cannot be tested. Therefore, we assess the likelihood of its validity by performing false experiments. In particular, we estimate the treatment effect as if the program was implemented before its actual inception date in 2009 . Table 4 reports the results of these placebo exercises, where no significant effects are found. This suggests that the observed changes in female labor force participation between groups took place after the introduction of the policy, but not earlier.

Table 3 Effect of AUH on the probability of entering the labor force. Difference-in-differences Probit estimates

\begin{tabular}{lllll}
\hline & All women & Single women & Married women & Men \\
\hline Treat $\times$ After & $-0.0216^{* * *}$ & -0.00427 & $-0.0262^{* *}$ & -0.0159 \\
& $(0.00807)$ & $(0.0319)$ & $(0.0117)$ & $(0.0121)$ \\
Observations & 22,251 & 2899 & 19,352 & 4129 \\
Pseudo $R^{2}$ & 0.042 & 0.162 & 0.038 & 0.180 \\
\hline
\end{tabular}

Source: Authors' calculation based on EPH data. Note: Probit estimates. The sample includes inactive women or men (head of household or spouse). The age range is 20-60 for women and 20-65 for men. The dependent binary variable equals 1 if the individual initially inactive experiences a transition to an active labor status. To apply a diff-in-diff specification, we include variables Treat (equals 1 for eligible inactive women-with children in poor and informal households), After (equals 1 for the period 2010-2013), and the interaction between them. We also add other control variables: age, squared age, educational level, marital status, binary indicators of the head of household and of whether the individual (or her/his spouse) is in charge of household chores, labor status of the spouse, per capita family income, family size, number of members by age and gender, region fixed effects, and time fixed effects (quarters). Clustered robust standard errors in parentheses. ${ }^{* * *} p<0.01 ;{ }^{* *} p<0.05 ;{ }^{*} p<0.10$ 
Table 4 Effect of AUH on the probability of entering the labor force. False experiments (placebo regressions)

\begin{tabular}{lllll}
\hline & \multicolumn{3}{l}{ False intervention in } & \\
\cline { 2 - 5 } & 2008 & 2007 & 2006 & 2005 \\
\hline Treat $\times$ After & -0.0143 & -0.00706 & 0.0114 & 0.00838 \\
& $(0.0129)$ & $(0.0163)$ & $(0.0102)$ & $(0.0121)$ \\
Observations & 10,700 & 10,700 & 10,700 & 10,700 \\
Pseudo $R^{2}$ & 0.044 & 0.044 & 0.044 & 0.044 \\
\hline
\end{tabular}

Source: Authors' calculation based on EPH data. Note: Probit estimates. The sample includes inactive married women between 20 and 60 years old (head of household or spouse). The dependent binary variable equals 1 if the woman initially inactive experiences a transition to an active labor status. For these placebo regressions, we restrict the sample to the period before the AUH (2005-2009). To apply a diff-in-diff specification, we include variables Treat (equals 1 for eligible inactive women-with children in poor and informal households), After (equals 1 for alternative false postintervention periods), and the interaction between them. We also add other control variables: age, squared age, educational level, marital status, binary indicators of the head of household and of whether the individual (or her/his spouse) is in charge of household chores, labor status of the spouse, per capita family income, family size, number of members by age and gender, region fixed effects, and time fixed effects (quarters). Clustered robust standard errors in parentheses. ${ }^{* * *} p<0.01$; ${ }^{* *} p<0.05 ;{ }^{*} p<0.10$

Another identification assumption is that there were no other contemporary events to the AUH that could have a differential incidence in the outcome of interest between groups. As discussed above, although it is not possible to rule out such contemporary events, this is likely to be the case: the AUH was the main social policy initiative in Argentina during the period under study (Rofman and Oliveri 2011), and it was not accompanied by any other social or employment initiative.

The results discussed so far are based on the comparison between eligible women and a control group that includes the rest of the women in our sample, i.e., inactive women aged 20-60 who do not have children under age 18, live in a non-poor household $^{22}$, and/or her spouse is registered in the labor market. To check for robustness of the results in Table 3, we estimate the impact of the AUH using four alternative control groups: (i) only non-eligible women with children, i.e., we drop women without children; (ii) only non-eligible women with no formal partner, i.e., we drop women married to formal workers; (iii) only non-eligible women in poor households, i.e., we drop nonpoor women; and (iv) non-eligible women with two of the three main requirements, i.e., combinations of the above groups taken in pairs. Table 5 shows that the estimated

Table 5 Effect of AUH on the probability of entering the labor force. Alternative control groups

\begin{tabular}{|c|c|c|c|c|c|}
\hline & \multicolumn{5}{|l|}{ Control groups } \\
\hline & Married women & With children (i) & Informal (ii) & Poor (iii) & P WCh, P I, I WCh (iv) \\
\hline \multirow[t]{2}{*}{ Treat $\times$ After } & $-0.0262^{* *}$ & $-0.0162^{*}$ & $-0.0427^{* * *}$ & $-0.0151^{* *}$ & $-0.0262^{* *}$ \\
\hline & $(0.0117)$ & $(0.00929)$ & $(0.0122)$ & $(0.00686)$ & $(0.0106)$ \\
\hline Observations & 19,352 & 12,916 & 9928 & 9870 & 10,836 \\
\hline Pseudo $R^{2}$ & 0.038 & 0.033 & 0.059 & 0.044 & 0.039 \\
\hline
\end{tabular}

Source: Authors' calculation based on EPH data. Note 1: Probit estimates. The sample includes inactive married women between 20 and 60 years old (head of household or spouse). The dependent binary variable equals 1 if the individual initially inactive experiences a transition to an active labor status. To apply a diff-in-diff specification, we include variables Treat (equals 1 for eligible inactive women-with children in poor and informal households), After (equals 1 for the period 2010-2013), and the interaction between them. We also add other control variables: age, squared age, educational level, marital status, binary indicators of the head of household and of whether the individual (or her/his spouse) is in charge of household chores, labor status of the spouse, per capita family income, family size, number of members by age and gender, region fixed effects, and time fixed effects (quarters). Clustered robust standard errors in parentheses. ${ }^{* *} p<0.01 ;{ }^{* *} p<0.05 ;{ }^{*} p<0.10$. Note 2: Alternative control groups (married women): (i) non-eligible women with children (i.e., we drop those women without children in the control group), (ii) non-eligible women in households with no formal partner, (iii) non-eligible women in poor households, and (iv) non-eligible women with two of the three main requirements-with children (WCh), poor (P), and with no formal partner (I) 
effects are all negative and significant, which reinforces the validity of the results found in Table 3. Depending on the control group, the fall in the probability of participating in the labor market for eligible married women ranges between 1.5 and 4.3 percentage points. This represents a minimum and maximum reduction of 14 and $41 \%$ of the expected outcome without the program.

\subsection{Heterogeneous effects}

It is important to further explore whether the unintended effect of the policy on female labor participation is heterogeneous across different groups of women. This may be both informative and explanatory of the aggregate result. Isolating the treatment effect on different groups of women could enable a better understanding of the transmission mechanisms on female labor force participation that are probably triggered by this policy. Again, the analysis focuses on married women, taking all non-eligible women in the sample as the control group.

First, we explore whether the effects vary depending on the labor condition of women's partners. Results in Table 6 suggest that disincentives to participate in the labor force operate particularly for mothers with employed husbands. In fact, labor participation decisions are expected to be more inelastic respect to the monetary transfers for women whose spouses are not employed. ${ }^{23}$

We also evaluate heterogeneous effects across education groups. The disincentive to labor participation seems to be important only for women with low levels of education (Table 7). This may reflect the fact that less educated women have fewer or less attractive labor opportunities, which makes them less willing to participate in the labor market after the introduction of the $\mathrm{AUH} .{ }^{24}$ In contrast, inactive women with potentially better employment perspectives do not seem to be significantly affected by the program, although the sign of the effect is still negative for this group.

Another heterogeneous impact of the AUH could be related to the number of children. ${ }^{25}$ Presumably, the larger the benefit from the program, the greater the disincentive to participate in the labor market. Assuming economies of scale in household consumption, a constant transfer per child implies that per capita benefit increases with the number of children. Therefore, under the hypothesis of negative income effects on labor supply, the program would have a negative effect on female labor force participation particularly relevant for mothers with many children. ${ }^{26}$ However, Table 8 shows a

Table 6 Effect of AUH on the probability of entering the labor force. Heterogeneities: spouse's labor condition

\begin{tabular}{llll}
\hline & Married women & Employed spouse & Not employed spouse \\
\hline Treat $\times$ After & $-0.0262^{* *}$ & $-0.0259^{* * *}$ & -0.0230 \\
& $(0.0117)$ & $(0.00891)$ & $(0.0283)$ \\
Observations & 19,352 & 16,833 & 2453 \\
Pseudo $R^{2}$ & 0.038 & 0.034 & 0.194 \\
\hline
\end{tabular}

Source: Authors' calculation based on EPH data. Note: Probit estimates. The sample includes inactive married women between 20 and 60 years old (head of household or spouse). The dependent binary variable equals 1 if the individual initially inactive experiences a transition to an active labor status. To apply a diff-in-diff specification, we include variables Treat (equals 1 for eligible inactive women-with children in poor and informal households), After (equals 1 for the period 2010-2013), and the interaction between them. We also add other control variables: age, squared age, educational level, marital status, binary indicators of the head of household and of whether the individual (or her/his spouse) is in charge of household chores, labor status of the spouse, per capita family income, family size, number of members by age and gender, region fixed effects, and time fixed effects (quarters). Clustered robust standard errors in parentheses. ${ }^{* *} p<0.01 ;{ }^{* *} p<0.05 ;{ }^{*} p<0.10$ 
Table 7 Effect of AUH on the probability of entering the labor force. Heterogeneities: woman's education

\begin{tabular}{llll}
\hline & Education & & \\
\cline { 2 - 4 } & Low & Medium & High \\
\hline Treat $\times$ After & $-0.0286^{*}$ & -0.00513 & -0.0620 \\
& $(0.0155)$ & $(0.0190)$ & $(0.0418)$ \\
Observations & 8061 & 8482 & 2809 \\
Pseudo $R^{2}$ & 0.064 & 0.055 & 0.089 \\
\hline
\end{tabular}

Source: Authors' calculation based on EPH data. Note: Probit estimates. The sample includes inactive married women between 20 and 60 years old (head of household or spouse). The dependent binary variable equals 1 if the individual initially inactive experiences a transition to an active labor status. To apply a diff-in-diff specification, we include variables Treat (equals 1 for eligible inactive women-with children in poor and informal households), After (equals 1 for the period 2010-2013), and the interaction between them. We also add other control variables: age, squared age, educational level, marital status, binary indicators of the head of household and of whether the individual (or her/his spouse) is in charge of household chores, labor status of the spouse, per capita family income, family size, number of members by age and gender, region fixed effects, and time fixed effects (quarters). Clustered robust standard errors in parentheses. ${ }^{* * *} p<0.01 ;{ }^{* *} p<0.05 ;{ }^{*} p<0.10$

significant negative impact for women with one or two children, but not for mothers with three children or more. This suggests that income effect is not the only-neither the most relevant-channel that could be actively operating (Ferro and Nicollela 2007; Gammage 2010). An alternative argument points out to the different elasticity of labor supply for women with different number of children. For instance, if the elasticity is larger among poor women with just one or two kids-who could find assistance for childcare from friends and relatives more easily than mothers with more children - then the results in Table 8 are easier to explain. If the AUH tends to increase mother's time spending on childcare (and hence discourage labor participation), then this potential change between eligible and ineligible groups may be negligible for large families. Childcare requirements are relatively high for mothers with many children, regardless the existence of the program.

Concerning the age of children, estimates in Table 9 indicate that the labor supply impact of the AUH seems to be present for women with children aged 7 or more, even though the effect is significant only for the group of mothers with children from 7 to 14 years old. ${ }^{27}$ The effect disappears in mothers with younger children. This heterogeneity may be consistent with the differential time required for taking care of children depending on their age. Also, access to public childcare services is

Table 8 Effect of AUH on the probability of entering the labor force. Heterogeneities: number of children

\begin{tabular}{llll}
\hline & \multicolumn{2}{l}{ Number of children } & \\
\cline { 2 - 4 } & $1-2$ & $3-4$ & 0.00846 \\
\hline Treat $\times$ After & $-0.0324^{* *}$ & 0.000196 & $(0.0262)$ \\
& $(0.0154)$ & $(0.0410)$ & 721 \\
Observations & 8504 & 3414 & 0.214 \\
Pseudo $R^{2}$ & 0.039 & 0.085 &
\end{tabular}

Source: Authors' calculation based on EPH data. Note: Probit estimates. The sample includes inactive married women between 20 and 60 years old (head of household or spouse). The dependent binary variable equals 1 if the individual initially inactive experiences a transition to an active labor status. To apply a diff-in-diff specification, we include variables Treat (equals 1 for eligible inactive women-with children in poor and informal households), After (equals 1 for the period 2010-2013), and the interaction between them. We also add other control variables: age, squared age, educational level, marital status, binary indicators of the head of household and of whether the individual (or her/his spouse) is in charge of household chores, labor status of the spouse, per capita family income, family size, number of members by age and gender, region fixed effects, and time fixed effects (quarters). Clustered robust standard errors in parentheses. ${ }^{* * *} p<0.01$; ${ }^{* *} p<0.05$; ${ }^{*} p<0.10$ 
Table 9 Effect of AUH on the probability of entering the labor force. Heterogeneities: age of youngest child

\begin{tabular}{llllll}
\hline & \multicolumn{4}{l}{ Age of youngest child } \\
\cline { 2 - 6 } & $0-3$ & $4-6$ & $7-10$ & $11-14$ & $15-17$ \\
\hline Treat $\times$ After & 0.00247 & -0.00556 & $-0.0119^{*}$ & $-0.0361^{*}$ & -0.0586 \\
& $(0.00647)$ & $(0.0239)$ & $(0.00690)$ & $(0.0216)$ & $(0.0681)$ \\
Observations & 4889 & 2328 & 2346 & 1934 & 1261 \\
Pseudo $R^{2}$ & 0.064 & 0.094 & 0.097 & 0.128 & 0.227 \\
\hline
\end{tabular}

Source: Authors' calculation based on EPH data. Note: Probit estimates. The sample includes inactive married women between 20 and 60 years old (head of household or spouse). The dependent binary variable equals 1 if the individual initially inactive experiences a transition to an active labor status. To apply a diff-in-diff specification, we include variables Treat (equals 1 for eligible inactive women-with children in poor and informal households), After (equals 1 for the period 2010-2013), and the interaction between them. We also add other control variables: age, squared age, educational level, marital status, binary indicators of the head of household and of whether the individual (or her/his spouse) is in charge of household chores, labor status of the spouse, per capita family income, family size, number of members by age and gender, region fixed effects, and time fixed effects (quarters). Clustered robust standard errors in parentheses. ${ }^{* *} p<0.01 ;{ }^{* *} p<0.05 ;{ }^{*} p<0.10$

very limited in Argentina, while primary school coverage-starting at 6 years old-is almost universal (Gasparini and Marchionni 2015; Marchionni and Alejo 2015). ${ }^{28}$ For these reasons, the elasticity of labor supply may be lower for mothers with small kids and hence the impact of the program weaker.

The EPH survey identifies the two main individuals in charge of the domestic chores within the household-it could be just one. We evaluate heterogeneous effects depending on whether it is the woman, her husband, or other family member the one who bears most of the burden of domestic chores. Results in Table 10 suggest that the labor disincentive effect is particularly significant for women in charge of the housework and who do not receive any kind of domestic help from their spouse or any other household member. Instead, the disincentive to participate in the labor market disappears for women who are not in charge of household chores or who receive assistance in such activities from other individuals. In summary, our findings suggest that the cash transfers may be reinforcing the traditional gender roles-women at home, men in the market-in those households with an already traditional division of roles by gender. Although we are aware of the endogeneity problems behind these results, ${ }^{29}$ we believe they point to a potential problem of gender bias associated with the program design that deserves serious consideration.

Table 10 Effect of AUH on the probability of entering the labor force. Heterogeneities: who are in charge of domestic chores?

\begin{tabular}{|c|c|c|c|c|c|c|}
\hline & \multicolumn{2}{|l|}{ Women } & \multicolumn{2}{|l|}{ Spouse } & \multicolumn{2}{|c|}{ Other members } \\
\hline & Yes & No & Yes & No & Yes & No \\
\hline \multirow[t]{2}{*}{ Treat $\times$ After } & $-0.0284^{* * *}$ & -0.00731 & 0.00158 & $-0.0268^{* * *}$ & -0.0437 & $-0.0272^{* * *}$ \\
\hline & (0.00783) & $(0.0190)$ & $(0.0218)$ & $(0.00804)$ & $(0.0431)$ & (0.00832) \\
\hline Observations & 18,387 & 778 & 1100 & 18,161 & 2266 & 17,019 \\
\hline Pseudo $R^{2}$ & 0.038 & 0.205 & 0.206 & 0.037 & 0.139 & 0.036 \\
\hline
\end{tabular}

Source: Authors' calculation based on EPH data. Note: Probit estimates. The sample includes inactive married women between 20 and 60 years old (head of household or spouse). The dependent binary variable equals 1 if the individual initially inactive experiences a transition to an active labor status. To apply a diff-in-diff specification, we include variables Treat (equals 1 for eligible inactive women-with children in poor and informal households), After (equals 1 for the period 2010-2013), and the interaction between them. We also add other control variables: age, squared age, educational level, marital status, binary indicators of the head of household and of whether the individual (or her/his spouse) is in charge of household chores, labor status of the spouse, per capita family income, family size, number of members by age and gender, region fixed effects, and time fixed effects (quarters). Clustered robust standard errors in parentheses. ${ }^{* * *} p<0.01 ;{ }^{* *} p<0.05 ;{ }^{*} p<0.10$ 


\subsection{Impact on other labor transitions}

We also explore whether the AUH affects other labor transitions besides the one from inactivity to activity. In particular, we evaluate the potential incentive on active women to leave the labor market and become inactive and on employed women to quit their jobs and become unemployed or inactive. To that aim, we define new estimation samples and outcome variables. ${ }^{30}$ The results are reported in Table 11.

We find no evidence of changes in the probability that active women or men become inactive. This result suggests an asymmetric response to the income transfer of active and inactive women. Interestingly, these differential effects on female labor transitions may help us understand the observed fall of the labor force participation rate for eligible women after the $\mathrm{AUH}$ implementation. In fact, the latter event seems to be mainly explained by a lower entrance rate of eligible mothers into the labor force (Table 3) and not by a significant change between groups in the corresponding exit rate (Table 11).

The last columns of Table 11 show that both women and men do not experience a significant change in the transitions from employment to unemployment or inactivity after the AUH.

\subsection{Effect on labor intensity}

We finally evaluate the potential change in the total hours worked between groups, before and after the AUH. In this case, the analysis is restricted to those women who remain employed throughout the four quarters of each follow-up period. We estimate the treatment effect using the two-step Heckman selection model which allows us to correct the selection bias arising from female labor participation. This will be represented by the probability of women being employed during the whole monitoring period. To measure labor intensity, we calculate the change in the total hours worked per week normalized by the intertemporal average labor intensity of each woman. To carry out this methodology, we assume that there are certain women's characteristics that affect both labor participation and intensity (age, education, region) while others are specific explanatory factors of the total hours worked or the probability of being employed.

Table 11 Effect of AUH on the probability of exiting the labor force. Active-inactive, employed-not employed

\begin{tabular}{|c|c|c|c|c|}
\hline & \multicolumn{2}{|c|}{ Active-inactive } & \multicolumn{2}{|c|}{ Employed-not employed } \\
\hline & Women & Men & Women & Men \\
\hline \multirow[t]{2}{*}{ Treat $\times$ After } & 0.00239 & 0.00212 & 0.00125 & -0.000957 \\
\hline & $(0.00665)$ & $(0.00403)$ & $(0.00739)$ & $(0.00578)$ \\
\hline Observations & 34,491 & 47,092 & 32,666 & 44,633 \\
\hline Pseudo $R^{2}$ & 0.087 & 0.112 & 0.074 & 0.059 \\
\hline
\end{tabular}

Source: Authors' calculation based on EPH data. Note: Probit estimates. The sample includes active (employed) women or men (head of household or spouse). The age range is 20-60 for women and 20-65 for men. The dependent binary variable equals 1 if the individual experiences a transition towards inactivity (not-employed) from an active (employed) labor status. To apply a diff-in-diff specification, we include variables Treat (equals 1 for eligible women-with children in poor and informal households), After (equals 1 for the period 2010-2013), and the interaction between them. We also add other control variables: age, squared age, educational level, marital status, binary indicators of the head of household and of whether the individual (or her/his spouse) is in charge of household chores, labor status of the spouse, per capita family income, family size, number of members by age and gender, region fixed effects, and time fixed effects (quarters). Clustered robust standard errors in parentheses. ${ }^{* * *} p<0.01 ;{ }^{* *} p<0.05 ;{ }^{*} p<0.10$ 
As it was shown above, the program does not seem to have generated a sufficient stimulus for active or employed women to move out of the labor force. However, it is possible that eligible employed mothers may be driven to work fewer hours compared to the counterfactual situation in the absence of the policy. We hence explore the potential effect of the AUH on female labor intensity (hours of work), following the arguments in Section 3 and applying the methodology described above for this purpose (two-step Heckman selection model). Table 12 shows a significant fall in the total working hours of beneficiary women after the AUH. Again, the effect is particularly significant for married women, whereas the impact disappears for single mothers. Male hours of work do not change between eligible and non-eligible groups with the introduction of the AUH.

This female labor intensity effect represents an average reduction of $6.5 \%$ of mean working hours, which is equivalent to an average fall of almost $3 \mathrm{~h}$ per week. However, contrary to the results for labor participation, Table 13 suggests that the impact on hours of work is not robust to different specifications of the control group.

\section{Conclusions}

We assess the impact on female labor force participation of a conditional cash transfer program implemented in Argentina in 2009 that delivers cash benefits to poor and non-formal households with children. For this purpose, and given the program design

Table 12 Effect of the AUH on labor intensity. Women and men (total hours worked)

\begin{tabular}{|c|c|c|c|c|c|}
\hline & $\begin{array}{l}\text { Women } \\
\text { (without Heckman) }\end{array}$ & $\begin{array}{l}\text { All } \\
\text { women }\end{array}$ & $\begin{array}{l}\text { Married } \\
\text { women }\end{array}$ & $\begin{array}{l}\text { Single } \\
\text { women }\end{array}$ & Men \\
\hline \multirow[t]{2}{*}{ Treat $\times$ After } & $-0.0872^{* *}$ & $-0.0652^{* * *}$ & $-0.0759^{* *}$ & -0.0519 & -0.0155 \\
\hline & $(0.0345)$ & $(0.0236)$ & $(0.0317)$ & $(0.0355)$ & $(0.0540)$ \\
\hline Individual and household characteristics & Yes & Yes & Yes & Yes & Yes \\
\hline Regional and time dummies & Yes & Yes & Yes & Yes & Yes \\
\hline \multirow[t]{2}{*}{ Mills lambda } & - & 0.437 & 0.326 & 0.238 & 2.060 \\
\hline & - & $(1.230)$ & $(1.107)$ & $(0.703)$ & $(5.026)$ \\
\hline Rho & - & 0.694 & 0.519 & 0.378 & 1.000 \\
\hline Sigma & - & 0.630 & 0.629 & 0.630 & 2.060 \\
\hline Lambda & - & 0.437 & 0.326 & 0.238 & 2.060 \\
\hline Observations & 28,102 & 65,722 & 50,349 & 15,373 & 58,243 \\
\hline Censored & - & 37,620 & 31,286 & 6334 & 12,882 \\
\hline Not censored & - & 28,102 & 19,063 & 9039 & 45,361 \\
\hline$R^{2}$ & 0.006 & - & - & - & - \\
\hline Wald chi ${ }^{2}(57)$ & - & 116.58 & 90.59 & 80.12 & 7.54 \\
\hline
\end{tabular}

Source: Authors' calculation based on EPH data. Note 1: Sample is restricted to employed individuals during the whole period (the age range is 20-60 for women and 20-65 for men). The dependent variable measures the change in the total hours worked per week normalized by the intertemporal average labor intensity of each woman/man. To apply a diff-in-diff specification, we include variables Treat (equals 1 for eligible women/men-with children in poor and informal households), After (equals 1 for the period 2010-2013), and the interaction between them (Treat $\times$ After). We also add other control variables: age, squared age, educational level, marital status, the activity sector in which she/he is employed, binary indicators of the head of household and of whether the individual is in charge of household chores, labor status of the spouse, per capita family income, family size, number of members by age and gender, region fixed effects, and time fixed effects (quarters). Clustered robust standard errors in parentheses. ${ }^{* * *} p<0.01 ;{ }^{* *} p<0.05$; ${ }^{*} p<0.10$. Note 2: Two-step Heckman selection model is applied to correct the selection bias arising from labor participation equation (probability of being employed in all periods we observe each individual). The selection equation to obtain Heckman's twostep consistent estimates includes the following control variables: age; squared age; educational level; marital status; binary indicators of the head of household, if she/he lives in poor, informal households with children, and of whether the individual (or her/his spouse) is in charge of household chores; region fixed effects; and time fixed effects (quarters) 
Table 13 Effect of the AUH on labor intensity. Alternative control groups

\begin{tabular}{llllll}
\hline & All women & With children (i) & Informal (ii) & Poor (iii) & P WCh, P I, I WCh (iv) \\
\hline Treat $\times$ After & $-0.0652^{* * *}$ & $-0.0657^{* * *}$ & -0.0594 & $-0.0623^{*}$ & $-0.0535^{*}$ \\
& $(0.0236)$ & $(0.0251)$ & $(6346)$ & $(0.0320)$ & $(0.0290)$ \\
Individual and & Yes & Yes & Yes & Yes & Yes \\
household characteristics & & & & & \\
Regional and time dummies & Yes & Yes & Yes & Yes & Yes \\
Mills lambda & 0.437 & 0.111 & 141,726 & 0.555 & -0.257 \\
& $(1.230)$ & $(0.929)$ & $(3.623 e+10)$ & $(0.432)$ & $(0.593)$ \\
Rho & 0.694 & 0.175 & 1.000 & 0.850 & -0.398 \\
Sigma & 0.630 & 0.636 & 141,726 & 0.652 & 0.644 \\
Lambda & 0.437 & 0.111 & 141,726 & 0.555 & -0.257 \\
Observations & 65,722 & 41,240 & 31,574 & 26,628 & 30,442 \\
Censored & 37,620 & 24,030 & 22,317 & 19,490 & 21,765 \\
Not censored & 28,102 & 17,210 & 9257 & 7138 & 8677 \\
Wald chi ${ }^{2}$ (57) & 116.58 & 106.95 & 0.00 & 64.05 & 70.72 \\
\hline
\end{tabular}

Source: Authors' calculation based on EPH data. Note 1: Sample is restricted to employed women during the whole period between 20 and 60 years old. The dependent variable measures the change in the total hours worked per week normalized by the intertemporal average labor intensity of each woman. To apply a diff-in-diff specification, we include variables Treat (equals 1 for eligible women-with children in poor and informal households), After (equals 1 for the period 2010-2013), and the interaction between them (Treat $\times$ After). We also add other control variables: age, squared age, educational level, marital status, the activity sector in which she is employed, binary indicators of the head of household and of whether the woman is in charge of household chores, labor status of her spouse, per capita family income, family size, number of members by age and gender, region fixed effects, and time fixed effects (quarters). Clustered robust standard errors in parentheses. ${ }^{* *} p<0.01 ;{ }^{* *} p<0.05 ;{ }^{*} p<0.10$. Note 2: Two-step Heckman selection model is applied to correct the selection bias arising from labor participation equation (probability of being employed in all periods we observe each woman). The selection equation to obtain Heckman's two-step consistent estimates includes the following control variables: age; squared age; educational level; marital status; binary indicators of the head of household, if she lives in poor, informal households with children, and of whether the woman (or her spouse) is in charge of household chores; region fixed effects; and time fixed effects (quarters). Note 3: Alternative control groups: (i) non-eligible women with children (i.e., we drop those women without children in the control group), (ii) non-eligible women in households with no formal partner, (iii) non-eligible women in poor households, and (iv) non-eligible women with two of the three main requirements-with children $(\mathrm{WCh})$, poor $(\mathrm{P})$, and with no formal partner (I)

and the nonrandom assignment of the beneficiaries, we use a non-experimental methodology of double differences and identify the potential participants according to the criteria and conditionalities of the program. The evidence suggests the existence of statistically significant disincentives to labor force participation of women driven by the program, but instead, we find nonsignificant effects for men. The AUH also seems to affect female labor intensity, although this result is not entirely robust to different alternative specifications of the control group.

The welfare implications of this result are not clear. Lower labor participation could be detrimental to women empowerment and may offset part of the poverty-reducing impact of the program. On the other hand, the monetary transfer of the program may allow poor women to avoid taking a low-pay job and instead stay at home with their children, which could be beneficial to their education given the scarcity of other goodquality options. More research is needed to have a more comprehensive view of these changes in behavior.

\section{Endnotes}

${ }^{1}$ See Bertranou et al. (2002), Levy (2008), Fiszbein and Schady (2009), Ibarrarán et al. (2017), UNDP (2011), Cruces and Gasparini (2012), and OIT (2012). 
${ }^{2}$ Gasparini and Marchionni $(2015,2017)$ relate the recent deceleration in female labor force participation in Latin America with the strong expansion of conditional cash transfer programs in the region.

${ }^{3}$ See Alzúa et al. (2013), Amarante et al. (2011b), Azuara and Marinescu (2013), Bosch and Manacorda (2012), Camacho et al. (2009), Bérgolo and Cruces (2013), Gasparini et al. (2009), Garganta and Gasparini (2015), and Banerjee et al. (2015).

${ }^{4}$ Most of the international literature confirms the labor supply theory predictions that the welfare system reduces labor participation and working hours. See, for instance, Moffitt (1992).

${ }^{5}$ Throughout the paper, we do not make distinctions between legally married women and women in consensual unions; for simplicity, we refer to both groups as married women.

${ }^{6}$ Unlike the effect of non-labor income transfers on married women, labor participation of single mothers tends to increase significantly in response to in-work benefits. For instance, Eissa and Liebman (1996) show that the expansion of the earned income tax credit (EITC) in 1986 increased labor force participation among single women with children in the USA. Similarly, Blundell et al. (2016) find that the UK tax credit system increased the labor supply of single mothers but decreased that of married women.

${ }^{7}$ See this discussion in Gasparini and Marchionni $(2015,2017)$ in the context of a general deceleration of female labor force participation in Latin America in the 2000s.

${ }^{8}$ Unlike the AUH, other cash transfer programs in Argentina were typically triggered by a socioeconomic emergency. The programs Trabajar in the mid-1990s and Jefes de Hogar in 2002 are the two main examples in this sense.

${ }^{9}$ Registered workers had already had a similar benefit (law 24.714 of 1996).

${ }^{10}$ The corresponding benefit for disabled children (no age restrictions) was initially set at ARS 720 .

${ }^{11}$ As for June 2015, the monthly transfer for disabled children was ARS 2730.

${ }^{12}$ In the next section, we also analyze other transitions potentially affected by the AUH: active-inactive and employed-not employed.

${ }^{13} \mathrm{We}$ do not include subsequent periods in order to isolate the estimation of this labor impact of the AUH from the potential labor incidence of the program PROGRESAR implemented in 2014. For a more detailed explanation of this policy, see http://www.progresar.anses.gob.ar/.

${ }^{14}$ The EPH asks salaried workers whether they contribute to the pension system through deductions from their wages as a way to identify informal labor arrangements. This is precisely the question used in the literature as the main proxy for informality (Tornarolli et al. 2014).

${ }^{15}$ Some self-employed workers could in principle be paying social security taxes and receiving basic social security coverage if their earnings are above some threshold, but almost no worker in our sample is in this situation.

${ }^{16}$ Results hold when using alternative income measures and poverty lines.

${ }^{17}$ There are other alternative ways to define the transition from inactivity to activity. For instance, we could check for inactivity (activity) in only one of the first (second) two appearances. We find that results hold when using different definitions of the transition.

${ }^{18}$ Also, the binary indicator After equals 1 for women that entered the EPH previous to the AUH inception but were interviewed for the last time after that moment. These 
women made the transition at some unobserved time that could be either before or after the AUH. Results are robust to changes in the way we treat these observations, i.e., to whether they are considered as part of the "before" or "after" period, or even when we exclude them from the sample.

${ }^{19} \mathrm{We}$ run the same exercise for men and the corresponding mean value for both the treatment and control group remain almost unchanged. Results are available upon request.

${ }^{20}$ The corresponding $F$ statistic is $F(18,12,178)=0.59$, with Prob $>F=0.91$. We run the same test restricting the analysis to married women and find similar results $(F(18,10,662)=0.66$, Prob $>F=0.85)$.

${ }^{21}$ The results of Table 3 hold when using the linear specification in Eq. 1. These OLS estimations are available upon request.

${ }^{22}$ Recall that even though family income is not monitored in practice, income poverty is a likely condition for households not to self-select out of the program.

${ }^{23}$ The non-significance of the coefficient in the last column may be also due to the small number of observations in this group.

${ }^{24}$ The international literature of welfare systems provides evidence of a negative elasticity of female labor force participation, which seems to be larger for the least skilled women and also declines with skill. See Anderson and Levine (2000) and Lehrer and Nerlove (1981) for a more detailed discussion of women's education and labor participation.

${ }^{25}$ For further discussion of the impact of children on women's labor supply, see Angrist and Evans (1998). These authors find that the labor market consequences of an increase in family size tend to be more severe for poor and less educated women.

${ }^{26}$ In a previous study of the AUH, Garganta and Gasparini (2015) find that the labor disincentive towards formality generated by the program is significantly higher for workers with more children.

${ }^{27}$ Although the estimated coefficient for the group of mothers with children aged 1517 is negative and relatively high, the corresponding treatment effect is not significant.

${ }^{28}$ For instance, based on a regression-discontinuity analysis for Argentina, Berlinski et al. (2011) find that preschool attendance of the youngest child in the household increases the probability of full-time employment and weekly hours of maternal employment.

${ }^{29}$ Women's decision not to participate in the labor market may in turn affect other household members' involvement with domestic chores.

${ }^{30}$ The sample for these new estimations includes active or employed women and men who are the spouse or the head of their households. The age range considered is also 20-60 for women and 20-65 for men. The outcome variables to measure these new labor changeovers are again binary indicators taking the value 1 for active (employed) women and men in year $t-1$ who make a transition to inactivity (unemployed or inactivity) during the following year (in year $t$ ).

\section{Acknowledgements}

We would like to thank the editor for the useful comments.

Responsible editor: Juan Jimeno

This paper was written as part of the project "Enhancing Women's Economic Empowerment Through Better Policies in Latin America," a joint initiative by CEDLAS and CIEDUR, supported by a grant from the International Development Research Centre (IDRC), Canada. The views expressed herein do not represent those of IDRC or its Board of Governors. The paper includes material from Santiago Garganta's Ph.D. dissertation at Universidad Nacional de La Plata. We are grateful to Cecilia Parada, Osvaldo Meloni, María Laura Lanzalot, and other seminar participants at UNLP, UdeSA, LACEA, The World Bank, and the 2015 annual meeting of AAEP (Asociación Argentina de Economía Política). All errors and omissions are the authors' sole responsibility. 


\section{Competing interests}

The IZA Journal of Labor Policy is committed to the IZA Guiding Principles of Research Integrity. The authors declare that they have observed these principles.

\section{Publisher's Note}

Springer Nature remains neutral with regard to jurisdictional claims in published maps and institutional affiliations.

Received: 26 April 2017 Accepted: 29 August 2017

Published online: 27 September 2017

\section{References}

Agis E, Cañete C, Panigo D (2010) Asignación Universal por Hijo en Argentina. Revista Aulas y Andamios № 8, Editora Aulas y Andamios, Fundación UOCRA, Buenos Aires. Available: http://www.fundacion.uocra.org/documentos/ recursos/articulos/Agis-Canete-Panigo-Asignacion-Universal-por-Hijo-en-la-Argentina.pdf

Ai D, y Norton EC (2003) Interaction terms in logit and probit models. Econ Lett 80:123-129

Alzúa ML, Cruces G, Ripani L (2013) Welfare programs and labor supply in developing countries. Experimental evidence from Latin America. J Popul Econ, Springer 26(4):1255-1284

Amarante V, Ferrando M, Vigorito A (2011) School attendance, child labour and cash transfers: an impact evaluation of PANES. Working Paper, No. 22/11, Poverty and Economic Policy Network-PIERI

Amarante V, Manacorda M, Vigorito A, Zerpa M (2011) Social assistance and labor market outcomes: evidence from the Uruguayan PANES. Inter-American Development Bank Regional Dialogue Labor Policy and Social Security Network, Washington DC

Anderson PM, Levine PB (2000) Child care and mothers' employment decisions. In: Card D, Blank RM (eds) Finding jobs: work and welfare reform. Russell Sage Foundation, New York

Angrist JD, Evans WE (1998) Children and their parents' labor supply: evidence from exogenous variation in family size. Am Econ Rev 88(3):450-477

ANSES (2014) Boletín Cuatrimestral Asignación Universal por Hijo para Protección Social. Observatorio de la Seguridad Social, ANSES, I Cuatrimestre 2014

Azuara O, Marinescu I (2013) Informality and the expansion of social protection programs. Evidence from Mexico. J Health Econ, Elsevier 32(5):938-950

Banerjee, A., Hanna, R., Kreindler, G and Olken, B. (2015). Debunking the stereotype of the lazy welfare recipient: evidence from cash transfer programs worldwide. MIT working paper

Bargain O, Doorley K (2011) Caught in the trap? Welfare's disincentive and the labor supply of single men. J Public Econ 95(9-10):1096-1110

Berger M, Black D (1992) Childcare subsidies, quality of care, and the labor supply of low-income, single mothers. Rev Econ Stat 74(4):635-642

Bérgolo M, Cruces G (2013) Informality, Contributory and Non Contributory Programmes. Recent Reforms to the Social Protection System in Uruguay. Development Policy Review 31(5): 531-551

Berlinski S, Galiani S, McEwan PJ (2011) Preschool and maternal labor market outcomes: evidence from a regression discontinuity design. Econ Dev Cult Chang, University of Chicago Press 59(2):313-344

Bertrand M, Duflo E, Mullainathan S (2004) How much should we trust difference-in-difference estimates? Q J Econ 119(1):249-275

Bertranou FM, Solorio C, van Ginneken W (2002) Pensiones No Contributivas y Asistenciales: Argentina, Brasil, Chile, Costa Rica y Uruguay. OIT, Santiago de Chile

Blundell R, Costa Dias M, Meghir C, y Shaw J. (2016) Female labor supply, human capital and welfare reform. Cowles Foundation Discussion Paper No. 1892RR

Boffi S (2013) Políticas de transferencias de ingresos. Su impacto en el mercado de trabajo. Experiencias en Latinoamérica y los casos de la Asignación Universal por Hijo y el Programa de Inclusión Previsional en Argentina. Publication № 16, Centro de Investigación en Trabajo, Distribución y Sociedad. Available: http://www.redetis.iipe. unesco.org/wp-content/uploads/2013/09/avances16-Polit-de-transf-de-ingresos.pdf

Bosch M, Manacorda M (2012) Social policies and labor market outcomes in Latin America and the Caribbean: a review of the existing evidence. Center for Economics Performance, London School of Economics and Political Science. Available: http://eprints.Ise.ac.uk/58003/1/_Ise.ac.uk_storage_LIBRARY_Secondary_libfile_shared_repository_ Content_Centre_for_Economic_Performance_Policy\%20Analysis_op032.pdf

Camacho A, Conover E, Hoyos A (2009) Effects of Colombia's social protection system on workers' choice between formal and informal employment. Working paper CEDE No. 2009-18

Card D (1990) The impact of the Mariel boatlift on the Miami labor market. Ind Labor Relat Rev 43(2):245-257

Card D, Krueger A (1994) Minimum wages and employment: a case of study of the fast-food industry in New Jersey and Pennsylvania. Am Econ Rev 84:772-793

Castillo N, Musante B, Mendoza Jaramillo A (2013) Aproximación a posibles efectos de la Asignación Universal por Hijo sobre el mercado de trabajo. VII Jornadas de Jóvenes Investigadores del Instituto de Investigaciones Gino Germani UBA. Available: http://jornadasjovenesiigg.sociales.uba.ar/files/2013/10/eje12_castillo_musante_mendoza.pdf

Cavalcanti T, Correa M (2010) Cash transfers and the labor market. Rev Bras Econ 64(2):175-190

Cruces G, Gasparini L (2012) Políticas sociales para la reducción de la desigualdad y la pobreza en América Latina y el Caribe, Premio Fundación 54 Vidanta 2012, Contribuciones a la reducción de la pobreza y la desigualdad en América Latina y el Caribe. Fundación Vidanta, México

Dabalen A, Kilic T, Wane W (2008) Social transfers, labor supply and poverty reduction: the case of Albania. World Bank Policy Research Working Paper 4783

Edmonds E, Schady N (2012) Poverty alleviation and child labor. Am Econ J Econ Pol, American Economic Association 4(4):100-124 
Edo M, Marchionni M, Garganta S (2015) Conditional cash transfer programs and enforcement of compulsory education laws. The case of Asignación Universal por Hijo in Argentina. Working Paper CEDLAS No. 190

Eissa N, Hoynes H (1999) The earned income tax credit and the labor supply of married couples. Department of Economics, Working Paper Series, Department of Economics, Institute for Business and Economic Research, UC Berkeley. Available: http://escholarship.org/uc/item/1024b9z8\#page-1

Eissa N, Hoynes H (2004) Taxes and the labor market participation of married couples: the earned income tax credit. J Public Econ, Elsevier 88(9-10):1931-1958

Eissa N, Liebman JB (1996) Labor supply response to the earned income tax credit. Q J Econ 111(2):605-637

Eyal K, Woolard I (2011) Female labour force participation and South Africa's child support grant. CSAE 25th Anniversary Conference 2011: Economic Development in Africa 2011

Ferro A, Nicollela A (2007) The impact of conditional cash transfer programs on household work decisions in Brazil. FEA-RP Working Paper Series

Fiszbein A, Schady N (2009) Conditional cash transfers. Reducing present and future poverty. World Bank, Washington D.C.

Franz W, Guertzgen N, Schubert S, Clauss M (2011) Assessing the employment effects of the German welfare reform: an integrated CGE-Microsimulation approach. Appl Econ 44(19):2403-2421

Galasso E (2006) With their effort and one opportunity: alleviating extreme poverty in Chile. Development Research Group, World Bank, Washington, DC

Gammage S (2010) Time pressed and time poor: unpaid household work in Guatemala. Fem Econ 16(3): 79-112

Garganta S, Gasparini L (2015) The impact of a social program on labor informality: the case of AUH in Argentina. J Dev Econ 115:99-110

Gasparini L, Cruces G (2010) Las asignaciones universales por hijo en Argentina: Impacto, discusión y alternativas. Económica LVI(1):105-146

Gasparini L, Haimovich F, Olivieri S (2009) Labor informality bias of a poverty-alleviation program in Argentina. J Appl Econ XII(2):181-205

Gasparini L, Marchionni M (eds) (2015) Bridging gender gaps? The rise and deceleration of female labor force participation in Latin America. CEDLAS UNLP. Available: www.labor-al.org/participacionfemenina. Accessed 8 Sept 2017

Gasparini L, Marchionni M (2017) Deceleration in female labor force participation in Latin America. Economía-LACEA Journal. Available: http://economia.lacea.org/Forthcoming\%20papers/02\%20Gasparini\%20\&\%20Marchionni_ final\%20draft\%20April\%202017.pdf

Ibarrarán P, Medellín N, Regalia F, Stampini M (eds) (2017) Así funcionan las transferencias condicionadas. Buenas prácticas a 20 años de implementación. Inter-American Development Bank. Available: https://publications.iadb.org/ bitstream/handle/11319/8159/Asi-funcionan-las-transferencias-condicionadas.PDF?sequence=7\&isAllowed=y. Accessed 8 Sept 2017

Kimmel J (1998) Childcare costs as a barrier to employment for single and married mothers. Rev Econ Stat 80(2):287-299

Kliksberg B, Novacovsky I (2015). El gran desafío. Romper la trampa de la desigualdad desde la infancia. Aprendizajes de la Asignación Universal por Hijo. Editorial Biblos

Lefebvre P, Merrigan P (2008) Childcare policy and labor supply of mothers with young children: a natural experiment from Canada. J Labor Econ 26(3):519-548

Lehrer E, Nerlove M (1981) The labor supply and fertility behavior of married women: a three period model. Res Popul Econ 3:123-145

Leibbrandt M, Lilenstein K, Shenker C, Woolard I (2013) The influence of social transfers on labour supply: a South African and international review. In: A Southern Africa Labour and Development Research Unit Working Paper Number 112. SALDRU, University of Cape Town, Cape Town

Lemieux T, Milligan K (2004) Incentive effects of social assistance: a regression discontinuity approach. University of California, Berkeley, Working Paper No. 70

Levy S (2008) Good intentions, bad outcomes: social policy, informality and economic growth in Mexico. Brookings Institution Press, Washington, DC

Levy S, Schady N (2013) Latin America's social policy challenge: education, social insurance, redistribution. J Econ Perspect 27(2):193-218

Marchionni M, Alejo J (2015) Funding basic education throughout the demographic transition in Argentina (chapter 8). In: Gragnolati M, Rofman R, Apella I, y Troiano S (eds) As time goes by in Argentina. Opportunities and challenges of the demographic transition. World Bank Group, Washington DC, pp 203-234

Maurizio R, Vazquez G (2014) Argentina: impacts of the child allowance programme on the labour-market behaviour of adults, CEPAL Review, No 113: 115-137. Available: http://repositorio.cepal.org/bitstream/handle/11362/37424/1/ RVI113Maurizio_en.pdf

Medeiros M, Britto T, Veras Soares F (2008) Targeted cash transfer programs in Brazil: BPC and Bolsa Familia. Working Paper, No. 46. Centro Internacional de Políticas para el Crecimiento Inclusivo, Brasilia

Michalopoulos C, Robins P, Garfinkel I (1992) A structural model of labor supply and childcare demand. J Hum Resour 27(1):166-203

Moffitt R (1992) Incentive effects of the U.S. welfare system. J Econ Lit 30(1):1-61

Naz G (2004) The impact of cash-benefit reform on parents' labour force participation. J Popul Econ 17(2):369-383

OIT (2012). Pisos de protección social para la justicia social y una globalización equitativa. International Labour Conference, 101st session 2012

Parker S, Skoufias E (2000) The impact of PROGRESA on work, leisure and time allocation. International Food Policy Research Institute, Washington, DC Final Report

Puhani P (2012) The treatment effect, the cross difference and the interaction term in nonlinear difference-in-difference models. Econ Lett, Elsevier 115(1):85-87

Ribar D (1995) A structural model of childcare and the labor supply of married mothers. J Labor Econ 13(3):558-597

Rofman R, Oliveri M (2011) Las Políticas de Protección social y su impacto en la distribución del Ingreso en Argentina. Working Paper Series on Social Policy No. 6, World Bank 
Scarlato M, D'Agostino G, Capparucci F (2014) Evaluating CCTs from a gender perspective: the impact of Chile Solidario on women's employment prospect. Munich Personal RePEc Archive. MPRA Paper No. 59414

Skoufias E, Di Maro V (2008) Conditional cash transfers, adult work incentives, and poverty. J Dev Stud 44(7):935-960

Skoufias E, Unar M, González-Cossío T (2008) The impacts of cash and in-kind transfers on consumption and labor supply: experimental evidence from rural Mexico. World Bank Policy Research Working Paper 4778

Stampini M, Tornarolli L (2013) The growth of conditional cash transfers in Latin America and the Caribbean: did they go too far?. Reunión Anual de la Asociación Argentina de Economía Política (AAEP)

Tamm M (2009) Child benefit reform and labor market participation. Ruhr Economic Papers, No. 97

Teixeira C (2010) A heterogeneity analysis of the Bolsa Familia program effect on men and women's work supply. International Policy Centre for Inclusive Growth, Working Paper No. 61

Terracol A (2009) Guaranteed minimum income and unemployment duration in France. Labour Econ 16(2):171-182

Tornarolli L, Battistón D, Gasparini L, Glüzmann P (2014) Exploring trends in labor informality in Latin America, 1990-2010. CEDLAS Working paper No. 159

UNDP (2011) Sharing innovative experiences: successful social protection floor experiences, vol 18. UNDP. Available: http:// www.ilo.org/wcmsp5/groups/public/—ed_protect/—soc_sec/documents/publication/wcms_secsoc_20840.pdf

Williams M (2007) The social and economic impacts of South Africa's child support grant. Economic Policy Research Institute Working Paper No 40

Submit your manuscript to a SpringerOpen ${ }^{\circ}$ journal and benefit from:

- Convenient online submission

- Rigorous peer review

Open access: articles freely available online

High visibility within the field

Retaining the copyright to your article

Submit your next manuscript at $\gg$ springeropen.com 